\title{
Assessment of physiological potential of cucumber seeds using the software Seedling Vigor Imaging System ${ }^{\circledR}\left(\text { SVIS }^{\circledR}\right)^{1}$
}

\author{
Adrielle Aparecida Chiquito ${ }^{2}$, Francisco Guilhien Gomes Junior², Julio Marcos-Filho*
}

\begin{abstract}
The software Seed Vigor Imaging System $\left(\right.$ SVIS $\left.^{\circledR}\right)$, has been successfully used to evaluate seed physiological potential by automated analyses of scanned seedlings. In this research, the efficiency of this system was compared to other tests accepted for assessing cucumber (Cucumis sativus L.) seed vigor of distinct seed lots of Supremo and Safira cultivars. Seeds were subjected to germination, traditional and saturated salt accelerated aging, seedling emergence, seedling length and SVIS analyses (determination of vigor indices and seedling growth uniformity, lengths of primary root, hypocotyl and whole seedlings). It was also determined whether the definition of seedling growth/uniformity ratios affects the sensitivity of the SVIS ${ }^{\circledR}$. Results showed that analyses SVIS have provided consistent identification of seed lots performance, and have produced information comparable to those from recommended seed vigor tests, thus demonstrating a suitable sensitivity for a rapid and objective evaluation of physiological potential of cucumber seeds. Analyses of four-days-old cucumber seedlings using the SVIS ${ }^{\circledR}$ are more accurate and growth/uniformity does not affect the precision of results.
\end{abstract}

Index terms: Cucumis sativus, quality control, germination, vigor.

\section{Avaliação do potencial fisiológico de sementes de pepino utilizando sistema computadorizado de análise de imagens de plântulas $\left(\mathrm{SVIS}^{\circledR}\right)$}

\begin{abstract}
RESUMO - O sistema computadorizado de análise de imagens de plântulas (SVIS ${ }^{\circledR}$ ) tem sido utilizado, com sucesso, para a determinação do potencial fisiológico de sementes, mediante avaliações do desenvolvimento de plântulas. Este trabalho teve como objetivo avaliar a eficiência desse sistema na avaliação do vigor de sementes de pepino (Cucumis sativus L.), em comparação com testes indicados para essa espécie. O trabalho foi desenvolvido com quatro lotes de sementes de pepino, cultivares Supremo e Safira, conduzindo-se testes de germinação, envelhecimento acelerado (tradicional e com solução saturada de $\mathrm{NaCl}$ ), emergência e comprimento de plântulas e análises SVIS ${ }^{\circledR}$, que determinam índices de vigor e de uniformidade de desenvolvimento de plântulas, comprimento da raiz primária, do hipocótilo e comprimento total das plântulas. Foi também verificado até que ponto a definição da proporção crescimento/uniformidade de desenvolvimento das plântulas afeta a sensibilidade do sistema. Os resultados das análises SVIS $^{\circledR}$ forneceram informações consistentes sobre o desempenho de lotes de sementes de pepino, demonstrando sensibilidade para a avaliação rápida e objetiva do potencial fisiológico. As análises pelo SVIS ${ }^{\circledR}$ em plântulas com quatro dias de idade são mais precisas e a proporção crescimento/ uniformidade para a composição do cálculo do índice de vigor não afeta a precisão dos resultados.
\end{abstract}

Termos para indexação: Cucumis sativus, controle de qualidade, germinação, vigor.

\footnotetext{
${ }^{1}$ Submitted on 09/27/2011. Accepted for publication on 12/11/2011.

${ }^{2}$ Departamento de Produção Vegetal, USP/ESALQ, Caixa Postal 9, 13418-900 - Piracicaba, SP, Brasil.

*Corresponding author $<$ juliomarcos.1@usp.br>
} 


\section{Introduction}

Research on seed vigor demands besides other objectives the development of methods to identify differences among seed lots according to their physiological potential providing results related to seedling establishment in the field and to storability. In addition, procedures have to be simple, reproducible, and provide rapid achievement of results.

Among tests used to assess cucumber seed vigor, literature includes the germination first count (Torres et al., 1999), traditional accelerated aging and saturated salt accelerated aging (Bhering et al., 2000; Abdo et al., 2005; Lima and Marcos-Filho, 2009), electrical conductivity (Abdo et al., 2005), controlled deterioration (Pandey et al., 1990; Alsadon et al., 1995), percentage or speed of seedling emergence (Barbedo et al., 1997; Lima and Marcos-Filho, 2009), and seedling length (Lima and Marcos-Filho, 2009).

Moreover, as the manifestation of seed vigor results from the interaction of characteristics that determine the potential for a rapid and uniform seedling emergence and stand establishment under a wide range of environmental conditions (Baalbaki et al., 2009), the use of a single vigor test classified as physiological, biochemical or expressing some kind of stress tolerance, may provide incomplete information (Hampton and Coolbear, 1990). Therefore, the predominant trend is the combination of different vigor test results taking into account the main objectives to be attained and the restrictions of each test.

In order to provide fast and consistent information on seed vigor, a relatively recent alternative is the use of digital analysis of seedling images, a procedure that does not involve direct interference of the seed analyst. Within this context, Sako et al. (2001) proposed an interesting alternative based on the automated analysis of lettuce (Lactuca sativa L.) seedling images considering the intensity, speed, and uniformity of growth. This way, the computer software Seed Vigor Imaging System - SVIS ${ }^{\circledR}$ was conceived and established.

The method consists, in a general way, in scanning images of young seedlings (three or four-day-old), which are immediately processed by a computer, generating numeric values (overall vigor and growth uniformity indices) based on pre-established parameters, to identify seed physiological potential (Sako et al., 2001).

After some few adaptations, this software was successfully used for other different plant species such as soybean [Glycine $\max (\mathrm{L})$ Merr.] (Hoffmaster et al., 2003;
Marcos-Filho et al., 2009), corn (Zea mays L) (Hoffmaster et al., 2005; Otoni and McDonald, 2005), and melon (Cucumis melo L.) (Marcos-Filho et al., 2006). Various studies are currently being carried out with seeds of other different cultivated plants, but there is still no information available on efficiency of system to evaluate the physiological potential of cucumber seeds.

The composition of this vigor index comprises the combination of seedling growth and uniformity of seedling development parameters. The SVIS $^{\circledR}$ has adjustments that allow for variation of this ratio for vigor index computation. Research references already mentioned were carried out adopting the 70:30 combination ratios for growth and uniformity, respectively. Gomes Junior et al (2009) obtained more consistent results using ratios of 70:30 for growth/uniformity as compared to $30: 70$ and 50:50 ratios to identify priming effects on sweet corn seeds. However, further research is still needed to verify what is the actual more adequate SVIS ${ }^{\circledR}$ procedure or whether some variation in these ratios are necessary, depending on seed sample or plant species involved. The studies must always include comparisons of SVIS ${ }^{\circledR}$ results to those form tests already indicated to determine seed vigor of different plant species.

Consequently, this research was carried out aiming to verify the efficiency of the Seed Vigor Imaging System (SVIS ${ }^{\circledR}$ ) to evaluate seed physiological potential as compared to other accepted tests for assessing cucumber seed vigor.

\section{Material and Methods}

Research was performed in Seed Analysis Laboratory and Laboratory of Images Analysis of Department of Crop Science/College of Agriculture "Luiz de Queiroz"/ University of São Paulo (USP), in Piracicaba, Brazil.

The experimental period, including assessment of physiological potential of cucumber seeds, in three distinct evaluation periods, with interval of approximately three months each, extended from November 2009 to July 2010. Within this period, seeds were stored into a dry chamber, under controlled environmental conditions $\left(20^{\circ} \mathrm{C}\right.$ temperature, and $50 \%$ relative humidity).

Seeds of two different cucumber cultivars, Supremo and Safira, each represented by four seed lots were used. Seed lots possessed initial higher than the minimum standard established for seed commercialization ( $80 \%)$, but differences in vigor. The following determinations were performed: 
Moisture content: evaluated by the oven method at $105 \pm 3{ }^{\circ} \mathrm{C}$, for $24 \mathrm{~h}$ (Brasil, 2009), before each test of germination and seedling emergence, and before and after the accelerated aging tests. Results were expressed in percent wet basis.

Germination: was performed with four replications of 50 seeds each, for each seed lot. Seeds were arranged on top of two sheets of paper towel moistened in the proportion of 2.5 times the weight of dry substrate, and covered with another moistened sheet after sowing. The paper towel sheets were then turned into rolls, which were maintained into a seed germinator at $25^{\circ} \mathrm{C}$. Seedling interpretation was performed four and eight days after sowing, according to the criteria established in the Rules for Seed Testing (Brasil, 2009). Results were expressed as percentage of normal seedlings for each lot and cultivar.

Traditional accelerated aging: this test was performed into individual compartments $(11 \mathrm{~cm} \times 11 \mathrm{~cm} \times 3.5 \mathrm{~cm}$ plastic germination boxes) where $40 \mathrm{~mL}$ of water were added at the bottom, according to Marcos-Filho (1999b). Seed samples (6 g each per seed lot) were spread, in a single layer, on top of aluminum screens suspended inside the gerbox, which were then maintained into a water jacketed chamber at $41{ }^{\circ} \mathrm{C}$ for $96 \mathrm{~h}$ (Lima and Marcos-Filho, 2009). After the accelerated aging, a germination test was carried out and the mean percent of normal seedlings, at the fourth day after seeding, was computed.

Saturated salt accelerated aging: this test was performed using the same procedures already described for the traditional accelerated aging test, except that 40 $\mathrm{mL}$ of saturated $\mathrm{NaCl}$ solution $(40 \mathrm{~g} \mathrm{NaCl}$ diluted in 100 $\mathrm{mL}$ of distilled water) substituted for water, thus providing a 76\% RH environment (Jianhua e McDonald, 1996).

Seedling length: at the upper third of paper towel sheets, moistened in the same manner previously described for germination test, four replications of 20 seeds each per seed lot were tested. Seeds were so placed in a manner to direct the micropyle to the bottom of substrate. The set was then kept in darkness, for four days, at $25^{\circ} \mathrm{C}$, into a seed germinator. Lengths of primary root and hypocotyl of normal seedlings were measured in millimeters with the aid of a ruler. Results were expressed as mean lengths of primary root and hypocotyl $(\mathrm{mm})$ per seed lot (Nakagawa and Vanzolini, 2007).

Seedling emergence: four replications of 50 seeds each, per seed lot, were used in this test. Seeds were sowed into polystyrene trays, with 200 cells per tray, containing Plantmax substrate. After sowing, the trays were kept at $25{ }^{\circ} \mathrm{C}$. Percent seedlings emergence was computed at the eighth day after sowing and the mean speed of seedling emergence for each seed lot and each cultivar was obtained by daily counting of seedlings and registration of seedling emergence speed index, according to Maguire (1962).

Analysis of seedlings digital images (software $\left.S V I S^{\circledR}\right)$ : in this test, four replications of 25 seeds each, per each seed lot, were germinated at $25{ }^{\circ} \mathrm{C}$ on moistened paper towels in the proportion of 2.5 times of water by weight of dry substrate. At the third or fourth day, seedling images were captured with the aid of a HP Scanjet G2410 scanner, fixed upside-down inside a 60 $\mathrm{cm} \times 50 \mathrm{~cm} \times 12 \mathrm{~cm}$ aluminum box, operated by the Photosmart software with a $100 \mathrm{dpi}$ resolution. Seedlings of each replication were then transferred from paper towel to a black $30 \mathrm{~cm} \times 20 \mathrm{~cm}$ cardboard rectangle, scanned at a 100 dpi resolution, and then analyzed by the software Seed Vigor Imaging System (SVIS ${ }^{\circledR}$ ), installed on a Pentium IV computer (2.0 GHz CPU, 768 MB RAM and $\mathrm{HD}$ of $40 \mathrm{~Gb}$ ), operated by a professional Windows XP system (Marcos-Filho et al., 2009). It was used a software developed for analyzing soybean seedlings adapted for melon seeds (Marcos-Filho et al., 2006).

During analyses, variations in seedlings growth/ uniformity ratios for composition of the overall vigor index parameter were evaluated to verify what proportion would provide best results (Figure 1). Therefore, the growth/uniformity ratios of 60:40, 70:30, and 80:20 were assessed. Both, growth and uniformity can vary from 0 to 1000 , based on the maximum size estimated for cucumber seedling growth. Values for maximum size of seedlings were established in preliminary tests performed under conditions already described for the germination test. Values of six inches $(15.24 \mathrm{~cm})$ for three-days-old seedling and nine inches $(22.86 \mathrm{~cm})$ for four-days-old seedlings were established. Records of these values in the program were performed as illustrated on Figure 1.

The lengths of primary root and of hypocotyl, as well as total length of each seedling were then determined positioning the cursor over each specific seedling to be evaluated and the software automatically marks this seedling in blue and registers its length (Figure 2). To assess lengths of primary root or hypocotyl it is necessary to manually highlight in blue the specific part of each seedling using the mouse (Figure 3). 


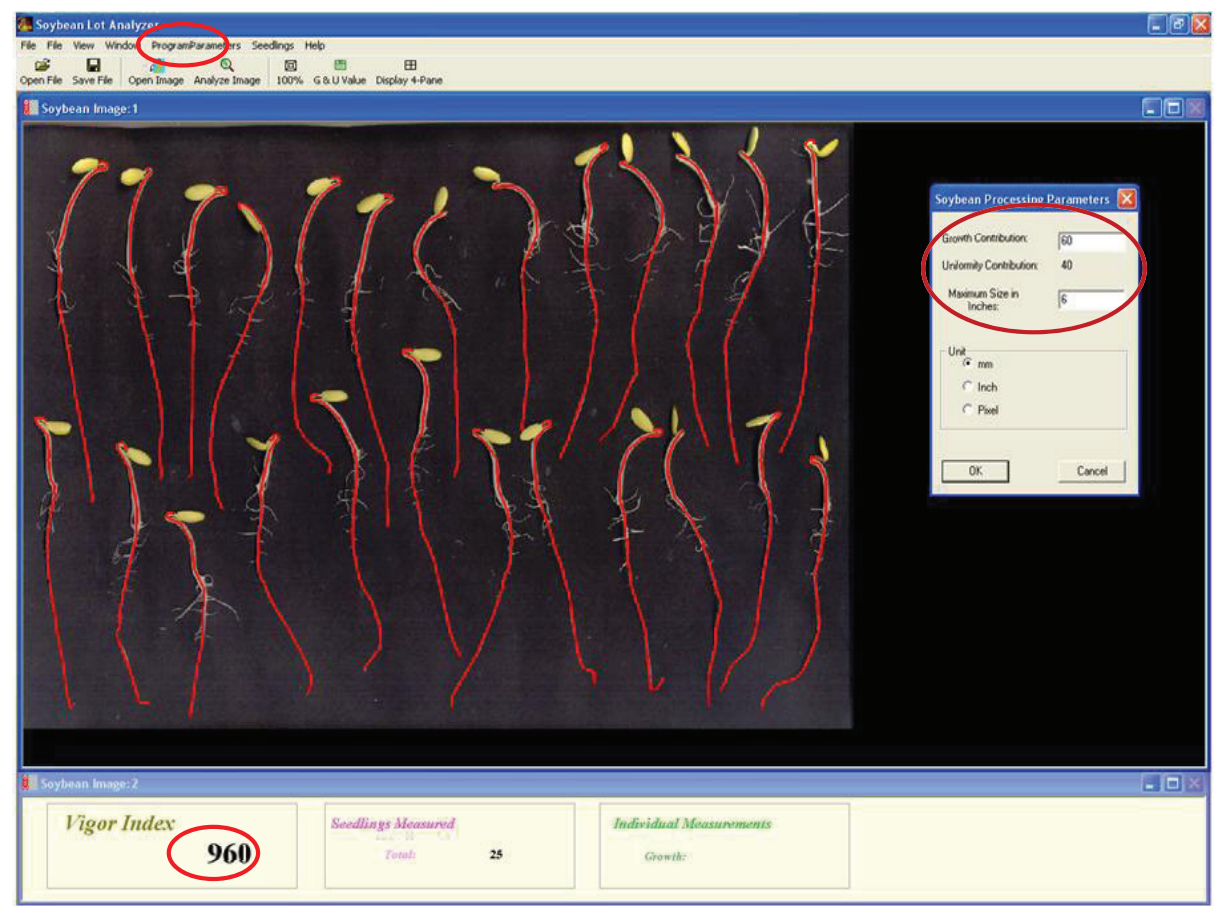

Figure 1. Digital images of cucumber seedlings, cv. Safira, assessed by the software SVIS ${ }^{\circledR}$ (Seed Vigor Imaging System). In highlight the menu indication "Program Parameters", where are adjusted the estimated maximum size of 3 day-old seedlings $(15.24 \mathrm{~cm})$ and growth/uniformity ratio (60:40) are indicated for vigor index computation (960, in this seed sample).

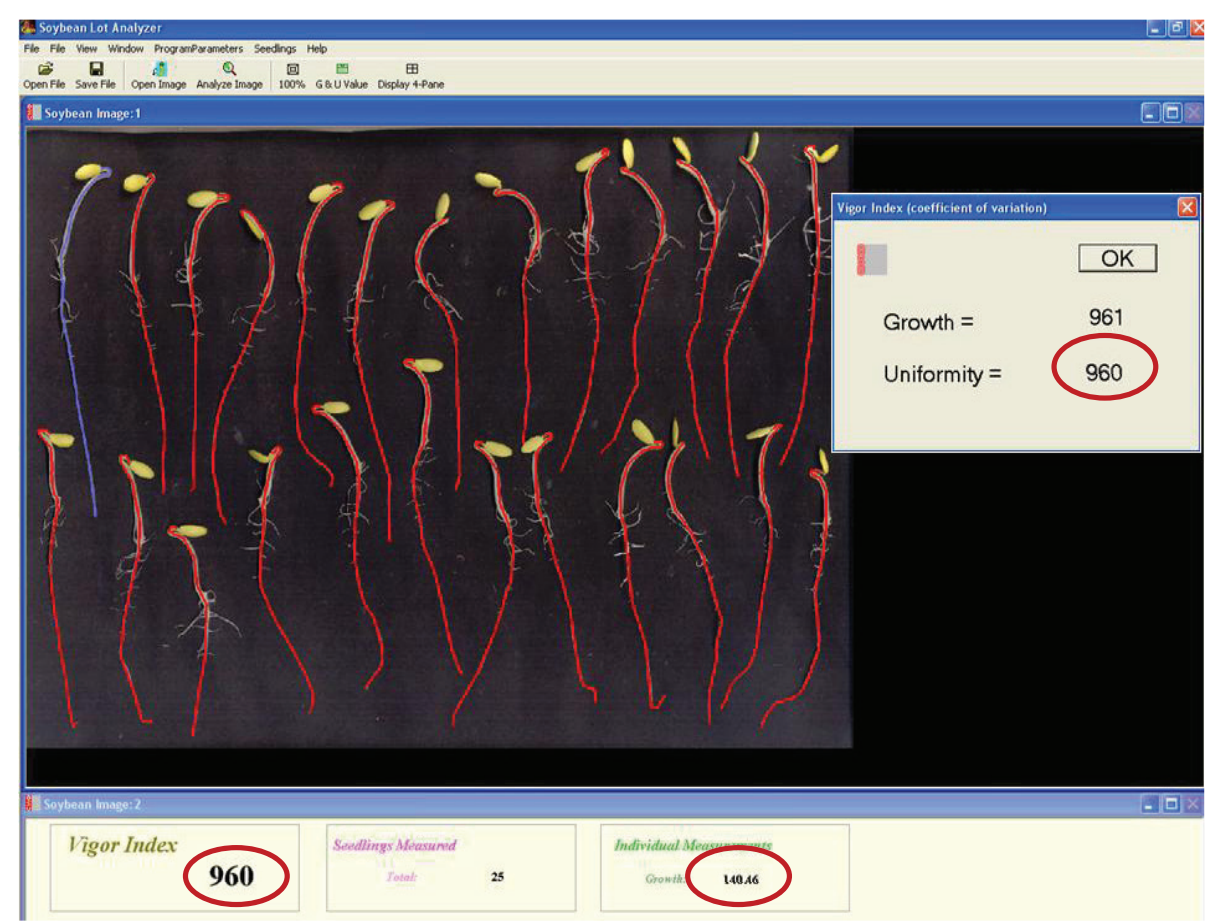

Figure 2. Digital images of 3 day-old cucumber seedlings, cv. Safira, from seed lot 4, and assessed by the software SVIS ${ }^{\circledR}$. In highlight: vigor index (960), uniformity of seedling development (960), and total seedling length (highlighted in blue color $-140.46 \mathrm{~mm}$ ) values. 


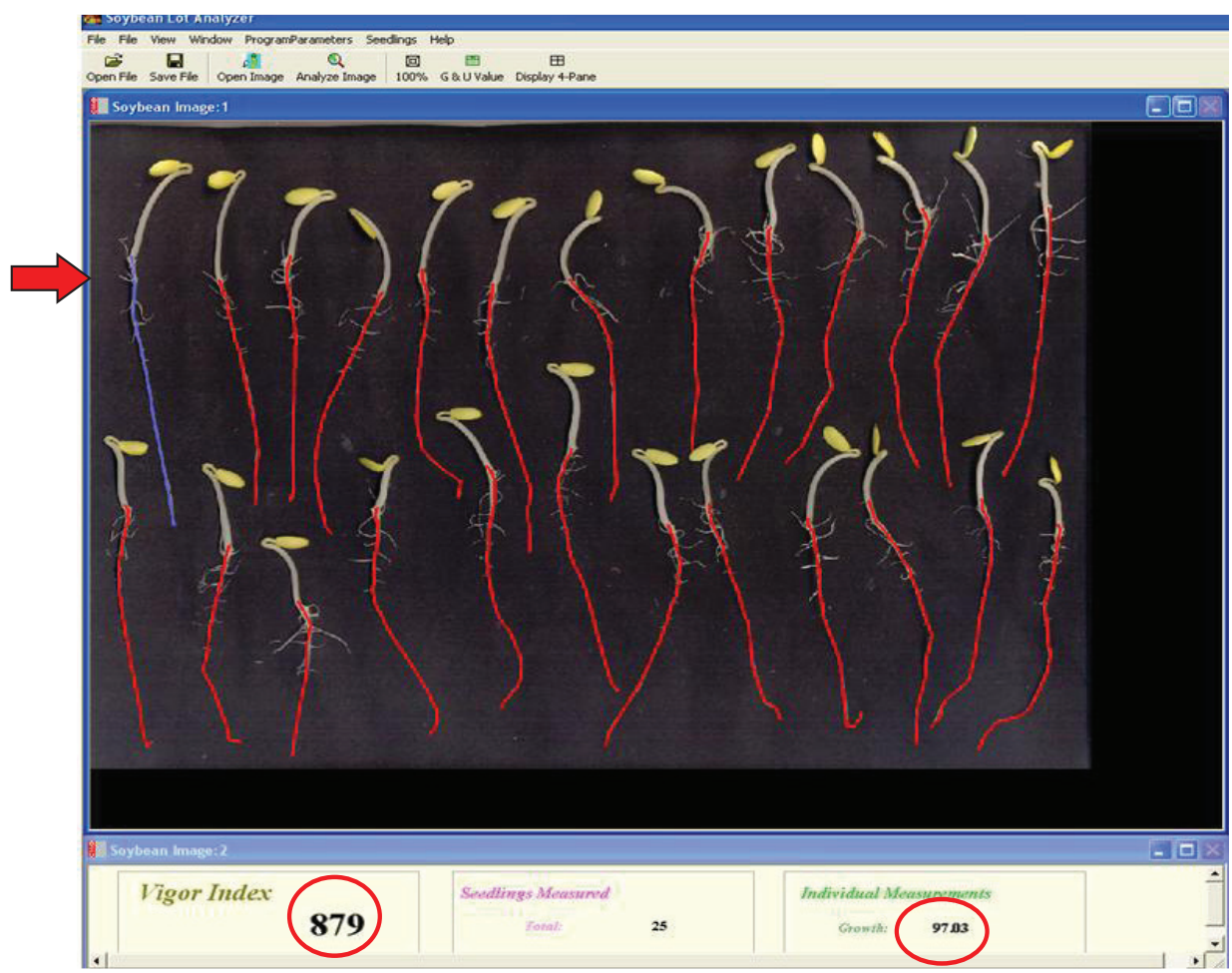

Figure 3. Digital images of 3 day-old cucumber seedlings, cv. Supremo, from seed lot 1, assessed by the software SVIS ${ }^{\circledR}$. In highlight: total length of primary root (in blue color at the upper left corner $-97.03 \mathrm{~mm}$ ), and vigor index (879) values.

Thus, after images processing, the mean values for vigor and growth uniformity indices as well as the total length of seedling and lengths of primary root and hypocotyl for each seed lot and cultivar were obtained, as reported by Hoffmaster et al. (2005) and Marcos-Filho et al. (2006). The time comprised from images capture by the scanner and the end of analysis for each replication, in general, was lower than five minutes.

Statistical procedures: data were separately analyzed for each test and cultivar, considering the set of evaluation times. For all tests performed, a completely randomized experimental design was used and the mean results were compared by the Tukey's test ( $\mathrm{p} \leq 0.05)$.

\section{Results and Discussion}

Vigor tests are essential tools for assessing physiological potential of seed lots, constituting basic parameters to compose seed quality control programs (Marcos-Filho, 1999a). For this reason, research on seed vigor must take into account seed lots of high germinability to compare performance of materials compatible with the requirements established for seed commercialization.
However, although basic procedures of various different vigor tests have already been established and actually provide reliable results, there are still opportunities for research continuity and for improvement of methodologies and/or the inclusion of new alternatives (Marcos-Filho et al., 2009).

On Tables 1 and 2, are shown the mean values from seed germination and vigor tests and from digital analyses of seedling images generated by analyses SVIS ${ }^{\circledR}$, respectively, for the four lots of cucumber seeds cv. Supremo, considering all evaluation times. Initial seed moisture content varied from 5.6\% to $6.7 \%$; which was considered adequate for performing germination and vigor tests, without possible significant influence on results.

Variation on seed moisture content from $22.0 \%$ to $24.5 \%$ after the traditional accelerated aging, and from $8.0 \%$ to $10.0 \%$ after the saturated salt accelerated aging were also within the limits previously established to assure uniformity conditions for the accelerated aging test (Marcos-Filho, 1999a). Decrease on speed and intensity of water uptake by seeds subjected to saturated salt accelerated aging test (SSAA), performed under lower relative humidity than that established for the traditional accelerated aging test (TAA) was also confirmed. Consequently, the SSAA effects were 
less drastic, as well as variations among replications, thus confirming observations from Bhering et al. (2000) and Abdo et al. (2005) for cucumber seed, and Panobianco and Marcos-Filho (2001) with tomato seeds.

Table 1 (cv. Supremo) shows the lower performance of seeds from lot 4 , for all tests performed, and also for lot 1 with respect to lengths of primary root and hypocotyl, speed of seedling emergence, and response to the TAA test. Such information is important because, once more, emphasizes the need for complementary results for the germination test with further data on seed vigor, so allowing for a proper use of seed lots. It has to be stressed that the four lots of the cv. Supremo had germination higher than $90 \%$ and even so were detected significant differences for seed physiological potential.

Table 1. Percent germination (G), primary root (PRL) and hypocotyl (HL) length, traditional (TAA) and saturated salt (SSAA) accelerated aging, speed of seedling emergence index (SSE) and percent seedling emergence (SE) of four cucumber seed lots, cv. Supremo. Means of three evaluation times.

\begin{tabular}{cccccccc}
\hline $\begin{array}{c}\text { SEED } \\
\text { LOT }\end{array}$ & G $(\%)$ & PRL $(\mathrm{cm})$ & HL $(\mathrm{cm})$ & TAA $(\%)$ & SSAA (\%) & $\begin{array}{c}\text { SSE } \\
\text { (index) }\end{array}$ & SE (\%) \\
\hline 1 & $99.0 \mathrm{a}^{*}$ & $9.0 \mathrm{~b}$ & $3.5 \mathrm{~b}$ & $75.0 \mathrm{~b}$ & $92.0 \mathrm{a}$ & $11.6 \mathrm{~b}$ & $97.0 \mathrm{a}$ \\
2 & $99.0 \mathrm{a}$ & $12.2 \mathrm{a}$ & $5.1 \mathrm{a}$ & $84.0 \mathrm{ab}$ & $95.0 \mathrm{a}$ & $14.0 \mathrm{a}$ & $97.0 \mathrm{a}$ \\
3 & $99.0 \mathrm{a}$ & $11.9 \mathrm{a}$ & $4.8 \mathrm{a}$ & $93.0 \mathrm{a}$ & $94.0 \mathrm{a}$ & $14.3 \mathrm{a}$ & $97.0 \mathrm{a}$ \\
4 & $90.0 \mathrm{~b}$ & $6.8 \mathrm{~b}$ & $3.3 \mathrm{~b}$ & $50.0 \mathrm{c}$ & $66.0 \mathrm{~b}$ & $12.7 \mathrm{~b}$ & $93.0 \mathrm{~b}$ \\
\hline CV (\%) & 3.1 & 11.4 & 10.0 & 9.7 & 6.2 & 3.5 & 2.8 \\
\hline
\end{tabular}

*Means comparison within each column by the Tukey’s test $(\mathrm{p} \leq 0.05)$.

One of the basic objectives of vigor tests is to consistently identify differences between high and low vigor seed lots in association to field seedling emergence results (Baalbaki et al., 2009). Nevertheless it was not possible identifying the most vigorous 'Supremo' seed lot, even under expected variation on sensitivity of each test. The efficiency of the vigor tests performed here confirms the observations of Lima and Marcos-Filho (2009) regarding the ability to rank seed lots of cucumber seeds.
Analysis of digital images performed by the software SVIS $^{\circledR}$ on seeds of 'Supremo' confirmed the lower performance of seed lot 4; there were no wide differences on results among the parameters studied, except for assessment of hypocotyl length and uniformity of growth (Table 2). The evaluation of primary root length was more precise also indicating the inferiority of seed lot 1 , either when performed on third day or at the fourth day after sowing.

Table 2. Mean data from SVIS analyses on four cucumber seed lots, cv. Supremo: primary root (PRL), hypocotyl (HL) and total seedling (SL) lengths, growth uniformity (GU) and vigor (VI) indices. Means of three evaluation times, varying the seedling growth/uniformity ratios for the determination of vigor index.

\begin{tabular}{ccccccccc}
\hline $\begin{array}{c}\text { Method/seedling } \\
\text { Age }\end{array}$ & $\begin{array}{c}\text { Seed } \\
\text { lot }\end{array}$ & PRL $(\mathrm{cm})$ & HL $(\mathrm{cm})$ & SL $(\mathrm{cm})$ & GU & \multicolumn{3}{c}{ VI } \\
\hline & 1 & $7.4 \mathrm{~b}^{*}$ & $2.1 \mathrm{a}$ & $9.1 \mathrm{a}$ & $921 \mathrm{a}$ & $918 \mathrm{a}$ & $800 \mathrm{ab}$ & $783 \mathrm{ab}$ \\
SVIS $^{\circledR}-3$ days & 2 & $8.4 \mathrm{a}$ & $2.5 \mathrm{a}$ & $10.1 \mathrm{a}$ & $939 \mathrm{a}$ & $926 \mathrm{a}$ & $924 \mathrm{a}$ & $922 \mathrm{a}$ \\
& 3 & $8.0 \mathrm{a}$ & $2.5 \mathrm{a}$ & $10.0 \mathrm{a}$ & $937 \mathrm{a}$ & $892 \mathrm{a}$ & $886 \mathrm{a}$ & $878 \mathrm{a}$ \\
& 4 & $5.1 \mathrm{c}$ & $2.2 \mathrm{a}$ & $6.6 \mathrm{~b}$ & $914 \mathrm{a}$ & $740 \mathrm{~b}$ & $711 \mathrm{~b}$ & $684 \mathrm{~b}$ \\
\hline $\mathrm{CV}(\%)$ & & 14.8 & 5.2 & 12.4 & 1.7 & 5.2 & 6.0 & 6.9 \\
\hline & 1 & $9.4 \mathrm{~b}$ & $3.5 \mathrm{bc}$ & $12.9 \mathrm{~b}$ & $933 \mathrm{a}$ & $850 \mathrm{a}$ & $803 \mathrm{ab}$ & $786 \mathrm{ab}$ \\
$\mathrm{SVIS}^{\circledR}-4$ days & 2 & $11.0 \mathrm{a}$ & $4.1 \mathrm{a}$ & $15.4 \mathrm{a}$ & $925 \mathrm{a}$ & $925 \mathrm{a}$ & $924 \mathrm{a}$ & $924 \mathrm{a}$ \\
& 3 & $10.9 \mathrm{a}$ & $3.8 \mathrm{ab}$ & $15.0 \mathrm{a}$ & $928 \mathrm{a}$ & $895 \mathrm{a}$ & $890 \mathrm{a}$ & $884 \mathrm{a}$ \\
& 4 & $6.8 \mathrm{c}$ & $2.8 \mathrm{c}$ & $9.4 \mathrm{c}$ & $893 \mathrm{a}$ & $742 \mathrm{~b}$ & $716 \mathrm{~b}$ & $695 \mathrm{~b}$ \\
\hline $\mathrm{CV}(\%)$ & & 11.9 & 11.5 & 10.2 & 2.5 & 4.8 & 5.5 & 6.2 \\
\hline
\end{tabular}

*Means comparison within each column by the Tukey's test $(\mathrm{p} \leq 0.05)$. 
Consequently, results from 'Supremo' seed lots showed that the use of software SVIS ${ }^{\circledR}$ has a similar efficiency to that found in tests already accepted to assess the physiological potential of cucumber seeds. This observation supports the information documented in the literature, among which those emphasized by Marcos-Filho et al. (2006) for melon seeds. Differences statistically significant were not detected for software sensitivity in scanned three or fourdays-old seedlings, even when different seedling growth/ uniformity ratios were examined for the composition of the computation of overall vigor index.

Seed lots of cultivar Safira showed initial moisture content from $4.7 \%$ to $6.6 \%$ during experimental period, and reached values varying from $8.1 \%$ to $8.3 \%$ after the SSAA test. Such variation on moisture content, however, was slightly higher than desirable after the TAA test, once values varied between $21.6 \%$ and $24.2 \%$. However, there was no significant effect on reliability of information provided by the accelerated aging test. Lima and Marcos-Filho (2009) also verified less drastic effects of the SSAA test as compared to the TAA test in cucumber seeds, but at the same time emphasized a possible lower sensitivity of the SSAA test to detect differences on physiological potential among seed lots, which was also detected here, mainly for 'Safira' seed lots.

There were no wide differences in vigor among seed lots of cv. Safira. Table 3 shows that seed lot 5 had the worst performance for primary root length evaluation, while seed lots 7 and 8 were considered less vigorous in the TAA test. Such contrast of results and the difficulty to identify vigor differences is not totally unexpected when seed lots of relatively high and uniform physiological potential are compared. This eventuality was confirmed by the percentage of seedling emergence in which, besides uniformity among seed lots, the very favorable environmental conditions prevailing during this test indeed contributed for high performance of all seed lots.

Table 3. Percent germination (G), primary root (PRL) and hypocotyl (HL) length, traditional (TAA) and saturated salt (SSAA) accelerated aging, speed of seedling emergence index (SSE) and percent seedling emergence (SE) of four cucumber seed lots, cv. Safira. Means of three evaluation times.

\begin{tabular}{cccccccc}
\hline $\begin{array}{c}\text { Seed } \\
\text { lot }\end{array}$ & G (\%) & PRL $(\mathrm{cm})$ & HL $(\mathrm{cm})$ & TAA (\%) & SSAA (\%) & SSE (index) & SE (\%) \\
\hline 5 & $100 \mathrm{a}^{*}$ & $10.9 \mathrm{~b}$ & $5.3 \mathrm{a}$ & $96 \mathrm{a}$ & $98 \mathrm{a}$ & $14.6 \mathrm{a}$ & $98 \mathrm{a}$ \\
6 & $100 \mathrm{a}$ & $12.2 \mathrm{a}$ & $6.0 \mathrm{a}$ & $94 \mathrm{a}$ & $95 \mathrm{a}$ & $14.5 \mathrm{a}$ & $99 \mathrm{a}$ \\
7 & $99 \mathrm{a}$ & $11.2 \mathrm{a}$ & $5.3 \mathrm{a}$ & $74 \mathrm{~b}$ & $97 \mathrm{a}$ & $15.0 \mathrm{a}$ & $100 \mathrm{a}$ \\
8 & $98 \mathrm{a}$ & $11.3 \mathrm{ab}$ & $5.5 \mathrm{a}$ & $78 \mathrm{~b}$ & $94 \mathrm{a}$ & $15.0 \mathrm{a}$ & $99 \mathrm{a}$ \\
\hline $\mathrm{CV}(\%)$ & 2.4 & 9.2 & 10.0 & 5.6 & 3.4 & 4.7 & 2.5 \\
\hline
\end{tabular}

*Means comparison within each column by the Tukey's test $(\mathrm{p} \leq 0.05)$.

In $\mathrm{SVIS}^{\circledR}$ evaluations performed on three-day-old seedlings there was also no significant differences among seed lots, except for seedling length and vigor index (70:30 ratio) as well as a general trend to inferiority of physiological potential in seeds of lot 7 (Table 4). These occurrences were more evident when SVIS ${ }^{\circledR}$ analyses were performed on four-daysold seedlings. Again, the seed lot with the highest physiological potential was not identified by any test performed.

This way, if data obtained for 'Safira' seed lots are considered, the evaluations in four-day-old seedlings using the software SVIS ${ }^{\circledR}$ should be recommended. Thus, this period can be more efficient when determinations are performed on seed lots with narrow variations on physiological potential, as emphasized by Marcos-Filho et al. (2006) in $\mathrm{SVIS}^{\circledR}$ analyses with melon seeds. Therefore, it is probable that for a more detailed examination of seed samples with high and uniform physiological potential it is necessary to extend the seedling evaluation time, for an additional period of $24 \mathrm{~h}$, to increase sensitivity of the $\mathrm{SVIS}^{\circledR}$ analysis.

In addition, with respect to variations in seedling growth/uniformity ratios $(60: 40,70: 30$ or $80: 20)$ for the composition of overall vigor index parameter, it was found that all three ratios studied allowed the differentiation in performance for seed lots of both cultivars in a coherently with the other tests performed here. As a consequence, as these studied ratios did not contribute in improving the sensitivity of the seedling image analyses by the software SVIS $^{\circledR}$, the 70:30 ratio, that is primarily used for seeds of other species, 
can be successfully recommended to standardize the composition of the vigor index computation for cucumber seeds.

Uniformity of seedling development did not differ among seed lots for the two cultivars (Tables 2 and 4), in contrast with Sako et al. (2001), Hoffmaster et al. (2005), and Marcos-Filho et al. (2006) findings. This can be attributed to similarity on physiological potential of seed lots assessed in the present research work. At the same time, it has to be stressed that seed vigor is expressed as a result of the interaction of several characteristics; this means that a given parameter should be sufficiently sensitive to rank lots according to seed physiological potential in a determined situation and less efficient in another different situation.

Table 4. Mean data from SVIS analyses on four cucumber seed lots, cv. Safira: primary root (PRL), hypocotyl (HL) and total seedling (SL) lengths, growth uniformity (GU) and vigor (VI) indices. Means of three evaluation times, varying the seedling growth/uniformity ratios for the determination of vigor index.

\begin{tabular}{ccccccccc}
\hline $\begin{array}{c}\text { Method/seedling } \\
\text { age }\end{array}$ & $\begin{array}{c}\text { Seed } \\
\text { lot }\end{array}$ & PRL $(\mathrm{cm})$ & HL $(\mathrm{cm})$ & SL $(\mathrm{cm})$ & GU & \multicolumn{3}{c}{ VI } \\
\hline & 5 & $8.1 \mathrm{a} *$ & $3.0 \mathrm{a}$ & $10.8 \mathrm{~b}$ & $927 \mathrm{a}$ & $933 \mathrm{a}$ & $934 \mathrm{a}$ & $925 \mathrm{a}$ \\
$\mathrm{SVIS}^{\circledR}-3$ days & 6 & $8.0 \mathrm{a}$ & $2.4 \mathrm{~b}$ & $12.6 \mathrm{a}$ & $936 \mathrm{a}$ & $936 \mathrm{a}$ & $936 \mathrm{a}$ & $935 \mathrm{a}$ \\
& 7 & $7.5 \mathrm{a}$ & $2.5 \mathrm{a}$ & $9.8 \mathrm{c}$ & $937 \mathrm{a}$ & $903 \mathrm{a}$ & $885 \mathrm{~b}$ & $891 \mathrm{a}$ \\
& 8 & $7.8 \mathrm{a}$ & $2.5 \mathrm{a}$ & $10.1 \mathrm{~b}$ & $928 \mathrm{a}$ & $927 \mathrm{a}$ & $927 \mathrm{a}$ & $927 \mathrm{a}$ \\
\hline $\mathrm{CV}(\%)$ & & 5.8 & 11.6 & 12.3 & 2.6 & 3.8 & 4.0 & 4.4 \\
\hline & 5 & $11.0 \mathrm{a}$ & $5.6 \mathrm{a}$ & $16.4 \mathrm{a}$ & $931 \mathrm{a}$ & $944 \mathrm{a}$ & $947 \mathrm{a}$ & $950 \mathrm{a}$ \\
$\mathrm{SVIS}^{\circledR}-4$ days & 6 & $11.4 \mathrm{a}$ & $5.9 \mathrm{a}$ & $17.3 \mathrm{a}$ & $934 \mathrm{a}$ & $953 \mathrm{a}$ & $956 \mathrm{a}$ & $960 \mathrm{a}$ \\
& 7 & $9.9 \mathrm{~b}$ & $4.6 \mathrm{~b}$ & $14.8 \mathrm{~b}$ & $916 \mathrm{a}$ & $874 \mathrm{~b}$ & $867 \mathrm{~b}$ & $860 \mathrm{~b}$ \\
& 8 & $10.7 \mathrm{a}$ & $5.4 \mathrm{a}$ & $16.1 \mathrm{a}$ & $949 \mathrm{a}$ & $949 \mathrm{a}$ & $950 \mathrm{a}$ & $950 \mathrm{a}$ \\
\hline $\mathrm{CV}(\%)$ & & 6.3 & 9.3 & 6.4 & 2.0 & 3.4 & 3.7 & 4.0 \\
\hline
\end{tabular}

*Means comparison within each column by the Tukey's test $(\mathrm{p} \leq 0.05)$.

In general, the objective of tests to assess seed physiological potential is to consistently distinguish seed lots with high performance potential from those with lower probability to provide an adequate stand establishment in the field after sowing or to identify differences in storability of seed lots. Information provided by different tests can be apparently contradictory, but it is not unusual that, in specific cases, seed samples which were ranked as vigorous can be classified as less vigorous by other test or tests. In addition, differences on sensitivity between tests may occur, depending on the parameter evaluated. Therefore, it is always convenient to evaluate physiological potential of seed lots at least with two different tests and to perform a careful interpretation of results in order to obtain high coherence in generating reliable information.

\section{Conclusions}

The use of software SVIS $^{\circledR}$ is an efficient alternative to assess the physiological potential of cucumber seeds in comparison to traditional vigor tests.

Analyses of total seedling length and lengths of primary root and hypocotyl performed by the software $\mathrm{SVIS}^{\circledR}$ on four-days-old cucumber (Cucumis sativus L.) seedlings are more precise. In addition, the growth/uniformity ratios for composition of the overall vigor index do not affect the precision of results.

\section{Acknowledgements}

The authors acknowledge the Fundação de Amparo à Pesquisa do Estado de São Paulo (FAPESP) and the Conselho Nacional de Desenvolvimento Científico e Tecnológico (CNPq), for the financial support to this research, and to Sakata Seed Sudamerica Ltd., for providing the cucumber seed lots.

\section{References}

ABDO, M. T. V. N.; PIMENTA, R. S.; PANOBIANCO, M.; VIEIRA, R. D. Testes de vigor para avaliação de sementes de pepino. Revista Brasileira de Sementes, v. 27, n. 1, p. 195-198, 2005. http://www.scielo. br/scielo.php?script=sci_arttext\&pid=S0101-31222005000100025\&lng $=\mathrm{pt} \& \mathrm{nrm}=\mathrm{iso} \& \mathrm{tlng}=\mathrm{pt}$ 
ALSADON, A.; YULE, L.J.; POWELL, A. A. Influence of seed ageing on the germination, vigour and emergence in module trays of tomato and cucumber seeds. Seed Science and Technology, v. 23, p. 665-672, 1995.

BAALBAKI, R.; ELIAS, S.; MARCOS-FILHO, J.; McDONALD. M. B. Association of official seed analysts. Seed vigor testing handbook. Ithaca, 2009. 341 p. (Contribuition, 32).

BARBEDO, A. S. C.; ZANIN, A.C. W.; BARBEDO, C. J.; NAKAGAWA, J. Qualidade fisiológica de sementes de pepino cv Pérola, em função da idade e do tempo de repouso pós-colheita dos frutos. Pesquisa Agropecuária Brasileira, v. 32, n. 9, p. 14-18, 1997. http://webnotes.sct. embrapa.br/pab/pab.nsf/20ef942c7775878a03256508004f3f7c/d7882c0 ccfdb8d3f0325650d00685ffb?OpenDocument

BHERING, M. C.; DIAS, D. C. F. S.; GOMES, J. M.; BARROS, D. I. Métodos para avaliação do vigor de sementes de pepino. Revista Brasileira de Sementes, v. 22, n. 2, p. 171-175, 2000. http://www.abrates. org.br/portal/revista/artigos-publicados

BRASIL. Ministério da Agricultura, Pecuária e Abastecimento. Regras para análise de sementes. Ministério da Agricultura, Pecuária e Abastecimento. Secretaria de Defesa Agropecuária. Brasília, DF: MAPA/ACS, 2009. 395p. http://www.agricultura.gov.br/arq_editor/file/ Laborat\%C3\%B3rio/Sementes/Regras\%20para\%20Analise\%20de \%20 Sementes.pdf

GOMES JUNIOR, F. G., MONDO, V. H. V.; CICERO, S. M.; McDONALD, M. B.; BENNETT, M. A. Evaluation of priming effects on sweet corn seeds by SVIS. Seed Technology, v.31, n.1, p.95-100, 2009.

HAMPTON, J. G.; COOLBEAR, P. Potential versus actual seed performance can vigour testing provide an answer. Seed Science and Technology, v. 18, n. 2, p. 215-228, 1990.

HOFFMASTER, A. L.; FUJIMURA, K.; McDONALD, M. B.; BENNET, M. A. An automated system for vigor testing three-day-old soybean seedlings. Seed Science and Technology, v. 31, n. 3, p. 701-713, 2003.

HOFFMASTER, A. L.; XU, L.; FUJIMURA, K.; McDONALD, M. B.; BENNET, M. A.; EVANS, A.F. The Ohio State University seed vigor imaging system (SVIS) for soybean and corn seedlings. Seed Technology, v. 27, n. 1, p. 7-26, 2005. http://seedbiology.osu.edu/People_pdf/miller_ abstractSVIScorn.pdf

JIANHUA, Z.; McDONALD, M. B. The saturated salt accelerated aging test for small-seeded crops. Seed Science and Technology, v. 25, n. 1, p. 123-131, 1996.

LIMA, L. B.; MARCOS-FILHO, J. Condicionamento fisiológico de sementes de pepino e relação com desempenho das plantas em campo. Revista Brasileira de Sementes, v. 31, n. 3, p. 27-37, 2009. http://www.scielo.
br/scielo.php?script=sci_arttext\&pid=S0101-31222009000300003\&lng=pt \&nrm=iso\&tlng $=\mathrm{pt}$

MAGUIRE, J. D. Speed of germination-aid in relation evaluation for seedling emergence vigor. Crop Science, v. 2, n. 2, p. 176-177, 1962.

MARCOS-FILHO, J. Teste de envelhecimento acelerado. In: KRZYZANOWSKI, F. C.; VIEIRA, R.D.; FRANÇA-NETO, J. B. (Ed) Vigor de sementes: conceitos e testes. Londrina: ABRATES, 1999a. p 1.1-1.24.

MARCOS-FILHO, J. Testes de vigor: importância e utilização. In: KRZYZANOWSKI, F. C.; VIEIRA, R. D.; FRANÇA-NETO, J. B. (Ed.). Vigor de sementes: conceitos e testes. Londrina: ABRATES, 1999b. cap. 1, p.1.1-1.21.

MARCOS-FILHO, J.; KIKUTI, A. L. P.; LIMA, L. B. Métodos para avaliação do vigor de sementes de soja, incluindo a análise computadorizada de imagens. Revista Brasileira de Sementes, v. 31, n. 1, p. 102-112, 2009. http://www.scielo.br/scielo.php?script=sci_ arttext\&pid=S0101-31222009000100012\&lng=pt\&nrm=iso\&tlng=pt

MARCOS-FILHO, J.; BENNETT, M. A.; McDONALD, M. B.; EVANS, A. F. GRASSBAUGH, E. M. Assessment of melon seed vigour by an automated computer imaging system compared to traditional procedures. Seed Science and Technology, v. 34, n. 2, p. 485-497, 2006.

NAKAGAWA, J.; VANZOLINI, S. Testes de vigor baseados no desenvolvimento de plântulas. Informativo ABRATES, v. 17, n. 1/3, p. 76-83, 2007.

OTONI, R. R.; McDONALD, M. B. Moisture and temperature effects on maize and soybean seedlings using the seed vigor imaging system. Seed Technology, v. 27, n. 2, p. 243-247, 2005.

PANDEY, P. K.; GOYAL, R. D.; PRAKASH, V.; JATIVER, R. P.; SINGH. Association between laboratory vigour tests and fields emergence in cucurbits. Seed Research, v. 18, p. 40-43, 1990.

PANOBIANCO, M.; MARCOS-FILHO, J. Envelhecimento acelerado e deterioração controlada em sementes de tomate. Scientia Agricola, v. 58 , n. 3 , p. $525-531,2001$. http://www.scielo.br/scielo.php?script $=$ sci_ arttext\&pid=S0103-90162001000300014\&lng=pt\&nrm=iso\&tlng=pt

SAKO, Y.; McDONALD, M. B.; FUJIMURA, K.; EVANS, A. F.; BENNET, M. A. A system of automated seed vigour assessment. Seed Science and Technology, v. 29, n. 3, p. 625-636, 2001.

TORRES, S. B.; VIEIRA, E. L.; MARCOS-FILHO, J. Efeitos do estresse hídrico na germinação e no desenvolvimento de plântulas de pepino. Revista Brasileira de Sementes, v. 21, n. 2, p. 59-63, 1999. http://www. abrates.org.br/portal/revista/artigos-publicados 